\title{
Education as a driver of economic growth of territories in the conditions of digital transformation
}

\author{
Inessa Vasileva $^{1^{*}}$, Natalia Morozova ${ }^{2}$, and Natalya Bondarenko ${ }^{1}$ \\ ${ }^{1}$ Chuvash State University, Russia
}

\begin{abstract}
The development and spread of digital technologies lead to serious qualitative changes not only in the field of industrial production. They have a strong impact on the social development of society, including education. The new technological (digital) revolution requires an individualized approach to meeting the economic and social needs of society. The digital revolution focuses on the quality of education based on the comprehensive development of each individual. Moreover, the tools of information and communication technologies used in the education system change depending on the conditions and settings of socio-economic development of the territory. Digital technologies have penetrated all spheres of society's life, which requires a new quality of education from every employee. In the modern world, a computer can replace about $62 \%$ of employees, and only $13 \%$ of people have a high level of intellectual literacy that surpasses computer systems [1]. The existing education system needs serious changes, since the system of modern training of workers is inferior to the level of training of workers who worked in the 90s. Moreover, the changes that are being made should also be individualized depending on the socio-economic requirements of the territory. The article identifies the main problems of socio-economic development of the Chuvash Republic. A number of projects are proposed that contribute to the development of the region's territory in the context of digital transformation.
\end{abstract}

\section{Introduction}

The fourth industrial revolution presents new challenges to society and the economy. The requirements of the digital economy have caused a gap between the human resources needs of business and the capabilities of the education system. The knowledge and competence of modern employees requires modification. Employees of all skill levels should have a high level of mathematical, financial and computer literacy, have the so-called "competence of the XXI century": project, digital, critical thinking [2]. The state and business have an objective need to predict and fix the appearance of new competencies [3].

\footnotetext{
* Corresponding author: inka107@mail.ru
} 
Issues of digital economy development are considered in the works of various philosophers, economists, and futurists. However, the process of digital transformation is a relatively new and large-scale phenomenon and, therefore, there are few economic studies devoted to this problem. Among domestic authors, we can distinguish the works of such scientists as Knobel A. Yu., Tolstykh T. O., Inozemtsev V. L., Idrisov G. I., Dementev V. E., Abroskin A. S., treshchevsky Yu. I., Zaitsev Yu. K., Ivanter V. V. Foreign authors include Bradley K., Freo M., Friedman D. F., Nicholson J. R., Curtis D., Blix M., Tucker K. E., Pearson T., Greenstein S. M., and others.

The existing research experience shows that in the modern economy, it is the digital transformation of the education system and innovation infrastructure that is a condition for competitiveness and sustainable socio-economic development of the territory [4].

\section{Materials and methods}

The theoretical and methodological basis of the research is the works of domestic and foreign scientists, which reflect the problems of socio-economic development of regions in the conditions of digital transformation.

The research is based on process, industry, and strategic approaches. The process approach to the study of regional development allows us to present the socio-economic system as a chain of processes that form a model of digital transformation of economic sectors. This approach allows you to decompose the production process, where each link of the transformation chain is "digitized", and the choice of a digitization tool depends on the capabilities of the territory. The industry approach allows us to analyze the structure of the model and its components, to study the intersectoral relationships of the transformed system with other industries, their forms and directions [5]. The strategic approach provides justification for the development of digital transformation mechanisms in the external environment that Orient strategic systems to development, associated with the identification of internal reserves of economic growth based on improving the efficiency of using all types of resources $[6,7]$.

To achieve the required quality of work, the following methods were used: methods of strategic planning; method of expert assessments; methodological approaches to welfare Economics, neo-institutional Economics; method of comparative dynamics; statistical methods; complex-target method.

\section{Results}

The Russian state has set an ambitious and extremely difficult goal -" to implement a breakthrough scientific, technological and socio-economic development of the Russian Federation, increase the country's population, improve the standard of living of citizens, create comfortable conditions for their living, as well as conditions and opportunities for self-realization and disclosure of the talent of each person" [8].

The main strategic priority of the Chuvash Republic is a stable improvement in the quality of life of the population of the Chuvash Republic based on the formation of a knowledge-based model of economic development, the key driving force of which will be human capital, in an ecologically clean, well-groomed, strong region. The basis of the economy should be high-tech and high-tech production (from the Strategy of socioeconomic development of the Chuvash Republic until 2035) [9].

During the period of implementation of the strategy of socio-economic development of the Chuvash Republic up to 2020 (2007-2017 years, excluding the financial crisis period), the gross regional product increased 1.2 times in comparable prices, industrial production - 
by 1.7 times, the volume of investments in fixed capital - in 1.1 times, retail trade turnover -1.6 times, real wages by 1.5 times.

During the period of implementation Of the strategy of socio-economic development of the Chuvash Republic until 2035 (2017-2035), it is planned to increase the volume of gross regional product per capita by 3.7 times, the volume of industrial production by 2.7 times, the volume of investment in fixed assets by 4.6 times, retail trade turnover by 3.6 times, and real wages by 2.0 times.

To do this, it is necessary to create at least one more economy in Chuvash Republic, comparable in scale to the existing one [10].

The main tool for implementing the Strategy is state programs as components of national projects.

Chuvash Republic is actively involved in national projects. However, out of 12 national projects, the Republic does not participate in the national project "Science", and in the national project "Education" almost none of the regional projects is related to the development of higher education. At the same time, it is the sphere of higher education and science that can undoubtedly provide conditions for sustainable and competitive socioeconomic development of the state and its regions.

Thus, in 2019, measures were implemented within the framework of 22 state programs of the Chuvash Republic. At the end of 2019, the new state program of the Chuvash Republic "Integrated development of rural territories of the Chuvash Republic" was approved by the resolution of the Cabinet of Ministers of the Chuvash Republic No. 606 dated December 26, 2019.

Currently, the Chuvash Republic participates in the implementation of 52 of the 67 Federal projects that are part of 11 national projects (programs). All regional projects are integrated into the state programs of the Chuvash Republic. The targets of regional projects and their funding are fully reflected in the state programs of the Chuvash Republic.

Expenditures of the Republican budget of the Chuvash Republic in 2019 amounted to 55183.1 million rubles. The main expenditure item (more than $31.8 \%$ ) is directed to education [11]. The cost structure is shown in figure 1.

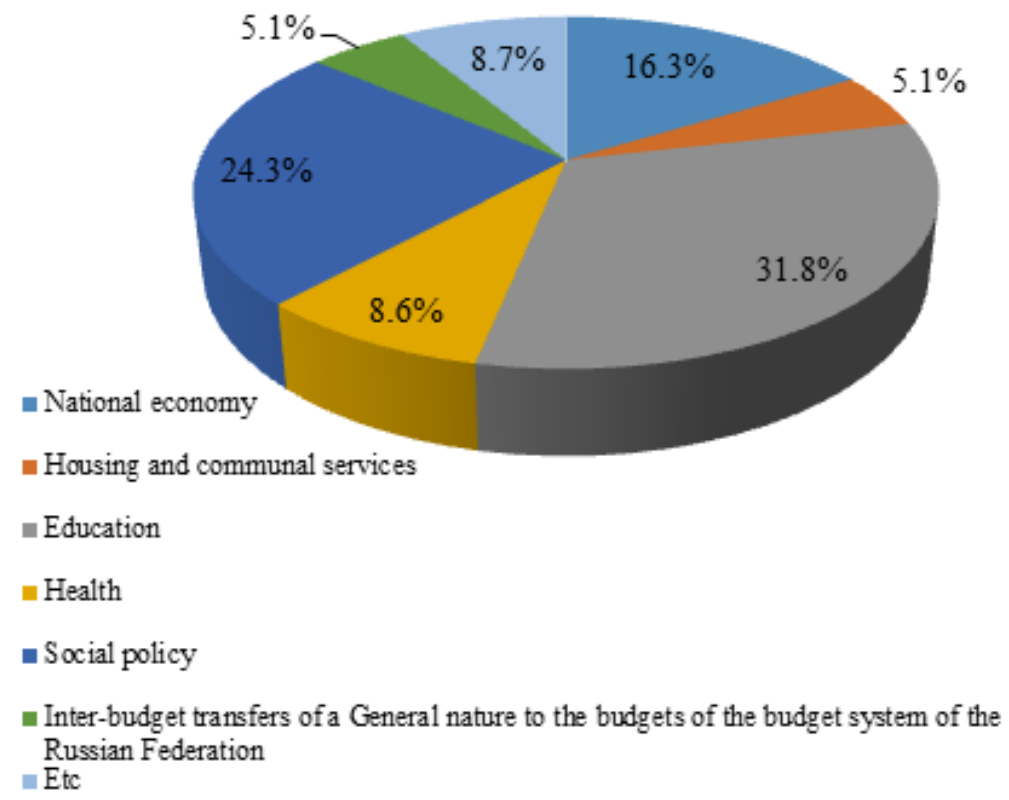

Fig. 1. Structure of expenditures of the Republican budget of the Chuvash Republic in 2019. 
The Republican budget surplus in 2019 amounted to 3465.9 million rubles.

The education system in the Chuvash Republic has consistently been a priority industry in recent years, with education expenditures in the consolidated budget of the Chuvash Republic for 2019 amounting to $34.3 \%$.

The average salary of teaching staff in educational organizations in 2019 was 25925.8 rubles, and preschool educational organizations-24103.1 rubles.

The system of preschool education is actively developing in the Republic. More than 76.5 thousand children are brought up in 333 kindergartens and pre-school groups at 199 schools.

From 2015 to 2019, 26 kindergarten buildings were built and reconstructed to ensure accessibility of preschool education, and 4844 places were created.

Various forms of pre-school education currently cover $78.5 \%$ of children aged 1 to 7 years. All children over the age of three are provided with places in kindergartens. In 19 municipalities children over one and a half years old are provided with places in kindergartens.

The availability of pre-school education for children from 1.5 to 3 years ( $\%$ of those who attend kindergartens from the number of applicants) is $83.5 \%$.

140767 children are enrolled in 417 General education organizations, of which 7779 children $(5.5 \%)$ are in the second shift.

In 2019 , the coverage of children aged 5 to 18 years enrolled in additional educational programs was $73 \%$.

Training of middle-level specialists and workers in the Chuvash Republic is conducted in 26 professional educational organizations and 5 branches of higher education organizations. In total, they train more than 27 thousand students [10].

Installation centers of working professions, multifunctional centers of applied qualifications, specialized resource centers, training centers and corporate centers of professional qualifications were opened. An interregional center of competence in the field of industrial and engineering technologies was created on the basis of Cheboksary electromechanical College, specializing in "Automation, radio engineering and electronics". About 700 million rubles were allocated for the creation and development of the center, which made it possible to create an innovative training center equipped with the most modern and high-tech equipment.

The Chuvash Republic became the second region of the Russian Federation to join the WorldSkills Russia movement. In the period from 2012 to 2019, seven regional Championships were held in 40 competencies.

In 2019, within the framework of the regional project "Young professionals" of the national project "Education", 50 workshops were created, equipped with modern equipment according to international standards.

However, the situation with qualified personnel in Chuvash Republic continues to be difficult. A strong outflow of young personnel reduces the pace of development of the territory. There is a significant outflow of applicants with high use scores to the capital's universities, many of whom do not return to Chuvash Republic after graduation. Also, the best graduates of colleges and universities prefer to continue their studies outside of Chuvash Republic and find a job there. In General, the level of migration of the population increased from 40 thousand people in 2014 to 51 thousand people in 2018. The situation is only getting worse, and its relevance will only increase over the years.

Another aspect of the problem is the reduction in the number of rural schools in the Chuvash Republic and children in them. In 2018, there were 317 rural schools in Chuvash Republic, 43.9 thousand children were enrolled in them (in 2004 - 467 schools, children 71.3 thousand) [11]. One of the reasons for the large outflow of population to cities is the 
lack of quality infrastructure, including educational [12]. There are problems in providing rural educational organizations with qualified teaching staff.

The presence of regional disparities between the labor market and the educational services market can be seen in table 1 .

Table 1. Setting Word's margins.

\begin{tabular}{|c|c|c|c|}
\hline $\begin{array}{c}\text { Subject of the } \\
\text { Russian Federation }\end{array}$ & $\begin{array}{c}\text { Percentage of } \\
\text { unemployed with } \\
\text { higher education, \% }\end{array}$ & $\begin{array}{c}\text { Need for } \\
\text { employees, 2018, } \\
\text { pers. }\end{array}$ & $\begin{array}{c}\text { Percentage of } \\
\text { employees with higher } \\
\text { education, 2018, \% }\end{array}$ \\
\hline Altai territory & 12.0 & 17416 & 27.4 \\
\hline Tula region & 17.0 & 17108 & 30.8 \\
\hline Leningrad region & 19.7 & 19315 & 31.3 \\
\hline Chuvash Republic & 20.1 & 18106 & 31.1 \\
\hline Chelyabinsk region & 20.2 & 20136 & 32.0 \\
\hline Khabarovsk territory & 20.5 & 16650 & 37.0 \\
\hline Belgorod region & 22.5 & 20110 & 31.7 \\
\hline
\end{tabular}

The state of the labor market in the region today is characterized by the average Russian level of the share of unemployed with a high need for workers and a relatively low share of employees with higher education.

Comparison of data shows the problem of discrepancy between the high proportion of people studying at the expense of the Federal budget in certain areas and specialties of training, the place in the structure of employed in the economy of the region with the remaining high demand for specialists in these areas (for example, qualified workers in agriculture and forestry).

The implementation of a number of projects on the territory of the Chuvash Republic can help solve the existing problem.

1. The project "Chuvash Republic - territory of opportunities":

- creation of an effective system of continuous multi-level education " student-entrantstudent-employee of the enterprise (organization)» ("Stairway to the future»);

- creation of specialized classes and basic schools with in-depth study of a particular subject on the basis of the Chuvash state University. Currently the University is already implementing a project for the development of engineering classes on the basis of schools in the Republic;

- formation of scientific and educational clusters (biomedical, engineering, design, etc. ) and improving the quality of educational programs through the creation of industry standards;

- a consortium of regional educational institutions and leading enterprises of the Chuvash Republic (or other network models of cooperation) for cooperation in education and research at the regional level; main directions of work: development and dissemination of the joint advanced educational programs and methods; joint research; education and training of teachers; creation of basic chairs at the enterprises;

- for the effective employment of graduates outreach to employers in the region to use the presidential platform "Russia - country of opportunities", including part of the project early professional orientation of pupils "Ticket to the future".

2. The project "Talents - to the economy of Chuvash Republic":

- motivation of talented graduates to enter higher education institutions of the Chuvash Republic;

- adoption of the regional law "On additional scholarships for students of state educational institutions of higher education", which provides for the provision of scholarships to students who entered Chuvash universities with high results of entrance tests; 
- creation of a mechanism for employers ' interest in establishing additional scholarships for talented students in Chuvash universities with their subsequent employment in the organization that pays the scholarship;

- creation of the Republican Fund for support of talented youth;

- implementation of measures to popularize scientific, educational and creative activities among children and youth, identification of talented youth (experience of ChSU - center for work with gifted youth, house of scientific collaboration named after S. A. Abrukov, Small electrotechnical Academy);

- training of teachers to work with gifted children and adolescents in the structure of a modern University complex.

3. The project "Digital ecosystem of Chuvash Republic"

- implementation of the target model of the digital educational environment that provides high quality and accessibility of education of all types and levels in General education organizations and professional educational organizations;

- this is curating schools-universities should create an ecosystem around themselves and offer online services to schools, introduce specialized classes in accordance with their own specializations;

- creation of pre-universities-development of the system of additional education, permanent circles, sections, workshops, discussion and humanitarian clubs, summer schools.

Currently, many rural schools are experiencing a shortage of qualified personnel, which results in an insufficiently high average score in the disciplines of the Unified state exam in the region, indicating the level of education.

Possible solutions are:

1. The project "University to rural school":

- involvement of University teaching staff in the educational process to conduct classes on subjects included in the Unified state exam (including on a distance basis), career guidance on the choice of training direction;

- organization of free "Summer schools" for schoolchildren on the basis of a local school, which will be conducted by teachers and active senior students of higher education institutions.

2. The project "The universal Teacher for a rural school»:

- implementation of the direction of personnel support of the General education system by training in higher education institutions in the target direction and concluding contracts with young specialists, according to which they must work for three years (five years) in rural schools of the Republic;

- use of financial and economic mechanisms to attract young professionals;

- providing young professionals with good housing conditions through the construction of transformer schools, where the school building has apartments for teachers, whose maintenance will be taken over by the municipality; it is also possible to make small kindergartens in the same premises;

- informatization and organization of teachers ' computer literacy improvement;

- since the situation with teachers of Russian and foreign languages and mathematics is difficult in the districts, it is possible to train universal teachers for rural, small-scale schools, who can teach several subjects of natural science (for example, simultaneously physics and chemistry) or the Humanities. Rural school teacher training is a process and result of reproduction, preservation and development of teaching staff in the agricultural sector of the Republic.

3. The project "Infrastructure of opportunities in rural areas"

Opportunities for rural teachers and school children to develop in various fields, both science, creativity, and sports. 
One of the problems of the modern education system is that the material and technical, educational, scientific and laboratory support of the educational process in higher education organizations of the Republic does not correspond to the current level of production development, especially in high-tech sectors of the economy, which negatively affects the quality of training of future specialists [13].

Student campuses of higher education institutions in Chuvash Republic do not fully meet modern standards and ideas about the comfort of the living environment of applicants and their parents, which negatively affects the indicators of providing educational services to non-resident applicants and attracting foreign specialists to cooperate. In addition, there is a shortage of places in student dormitories at a number of universities.

The following programs can help you do this:

1. The project "Network interaction - creation of an infrastructure-type University"

- creation of a scientific and educational center based on the integration of Chuvash universities and scientific organizations and their cooperation with organizations operating in the real sector of the economy ("Partner network»);

- formation of a network of reference universities as centers of innovative, technological and social development of the Chuvash Republic;

creation of the mechanism for support of higher education institutions of the Chuvash Republic from the region (co-financing of programs of development institutions in terms of logistics, including purchase of modern equipment for scientific and educational purposes, promoting research and scientific-pedagogical activity of the scientists working at the University, etc.);

- the creation of biomedical cluster of "treatment - rehabilitation - recreation", the development of medical tourism;

- formation of a University network of educational centers equipped with modern material and technical base (training facilities, computer equipment and licensed software, interactive and presentation equipment, furniture, consumables) in the municipalities of the republics: Alatyr, Kanash, Shumerlya, as more remote from Cheboksary and having a significant production base;

- creation and effective functioning of scientific and research centers and universities, formation of a society of qualified, dynamic and creative people with the prospects of obtaining a decent education and lifelong learning for all members of society;

- creation of effective organizational forms and business environment that promote the development of innovative entrepreneurship together with research centers, universities and other institutions.

2. The project "Internationalization of education" (within the framework of the project Export of education)

- active introduction of the international component in all functional areas of higher education institutions;

- student mobility as one of the most common and traditional forms of implementing the internationalization of higher education.

- expand the educational and cultural presence of Russia and Chuvash Republic in the world and, especially, in neighboring countries.

3. The project "Student campus-new quality - new opportunities":

- construction of new dormitories, including for foreign citizens;

- development of sports infrastructure (swimming pool, multifunctional outdoor and indoor sports grounds, GTO studios, etc.);

- development of creative infrastructure (Palace of culture, creative studios).

The development of the education system of the Chuvash Republic is an important condition for ensuring sustainable development of the region and increasing its competitiveness $[14,15]$. In the strategic perspective, this sphere will be focused on 
improving the availability and quality of services provided, training qualified personnel in demand on the labor market who can improve their skills throughout their lives and use their newfound competencies in their work, and improving the effectiveness of attracting active youth in the interests of innovative, socially oriented development of the region [16, $17,18]$.

A key role in this process should be assigned to the development of the higher education system within several development horizons.

\section{Conclusion}

The following areas are key to the development of the education system in the context of digital transformation:

- modernization of educational programs taking into account the system of professional standards and changing qualification requirements of the labor market and the population;

- improving the system for collecting and analyzing the needs of the regional labor market for qualified personnel in the medium and long term in order to take into account the results obtained in the distribution of places under the state order for education;

- development of a regional system of qualification certification for professional educational programs, which provides for the conduct of a qualification exam in real production;

- improvement of mechanisms aimed at attracting applicants from neighboring regions to professional educational organizations;

- development of the dual education system in secondary and higher education institutions of the region;

- development and implementation of incentive mechanisms for involving the real sector of the economy in the system of training specialists and evaluating their qualifications;

- additional support for educational programs of leading universities of the region at the regional level;

- creation of a scientific and educational complex in the region, and on its basis - a University campus for the preparation of all levels of education in accordance with the most modern requirements for the development of science and technology;

- providing additional measures of social support for graduates of educational organizations who are studying in the region's priority specialties and areas of training in the most key and popular areas of the economy.

It is necessary to form the framework of the University centres professional qualifications (resource centers) at the schools where it is expected the training software. Development and implementation of a mechanism for implementing network educational programs based on resource centers and their budget financing [19, 20].

Special attention should be paid to the implementation of a set of measures to modernize the training of teachers.

The reported study was funded by RFBR, project number 20-010-00683.

\section{References}

1. S.W. Elliott, Computers and the future of skill demand, P.: OECD Publishing (2017).

URL: http://www.oecd.org/edu/computers-and-the-future-ofskill-demand-

9789264284395-en.htm 
2. A.Yu. Uvarov, Education in the world of digital technologies: on the way to digital transformation, Publishing house of the higher school of Economics, Moscow (2018).

3. A.V. Ostrovsky, M.V. Kudina, New paradigm of education in the era of digital transformation of the state, State administration. Electronic Bulletin 78, 229-243 (2020).

4. D.P. Frolov, Institutional relations in society and economy, Theoretical Economics 1, 112-116 (2018).

5. Sh. Kudbiev, Methodological aspects of digital transformation, International scientific review LXVII (2020). URL: https://cyberleninka.ru/article/n/metodologicheskieaspekty-tsifrovoy-transformatsii

6. A. Sokolov, Model of management of sustainable balanced development of the region, Scientific review 5, 68-76 (2016).

7. E. Marcon, F. Puech, A typology of distance-based measures of spatial concentration, Regional Science and Urban Economics 62, 56-67 (2017).

8. Decree of the President of the Russian Federation of may 7, 2018 N 204 "On national goals and strategic objectives of the development of the Russian Federation for the period up to 2024". URL: http://www.kremlin.ru/acts/bank/43027

9. Strategy of socio-economic development of the Chuvash Republic until 2035. URL: http://minec.cap.ru/usercontent/economy/activities//254-2806_okonchateljnaya(1).pdf

10. Project of a Comprehensive program of socio-economic development of the Chuvash Republic, ZAO "International center for regional development", Moscow (2020).

11. Official website of the Federal state statistics service. URL: https://www.gks.ru/folder/10705

12. A.M. Mikhailov, Economic and institutional relations, Economic science 5, 48-52 (2017).

13. "Program of anticrisis measures of the Government of the Russian Federation", Phil. Economic policy of Russia - XXI century 3, 15-27 (2019).

14. I. Danilov, T. Ladykova, N. Morozova, E. Ilyina, State policy of staffing of global reindustrialization of national economy, Phil. Journal of advanced research in law and economics, 1-8, 18-22 (2017).

15. N. Tumalanov, N. Urusova, Impact of economic interests and institutional structures on economic development, Phil. Bulletin of Chuvash University 1, 245 (2014).

16. L. Progunova, T. Satsuk, A. Slavin, T. Veynbender, A. Perova, G. Sokolova, International standards of the public sector financial reporting in ensuring economic security, Revista Publicando 18-2, 330-340 (2018).

17. O.A. Romanova, Industrial policy priorities of Russia in the context of challenges of the fourth industrial revolution, Economy of Region 14(3), 806-819 (2018).

18. E.G. Mikhailova, M.Yu. Dyakov, The Choice of strategic directions of development of the region taking into account the requirements of sustainable development, Issues of regional economy 4(33), 35-47 (2017).

19. S. Nikonorov, From strategy of social and economic development to strategy of sustainable development of regions of Russia, Phil. Management and business administration 4, 28-35 (2016).

20. A.E. Yakovlev, N.V. Morozova, I.A. Vasileva, The Place and role of regions in the strategic development of the national economy, Publishing house "Perfectum", Cheboksary (2013). 